\title{
LATE ALBIAN - EARLY CENOMANIAN BASIN EVOLUTION USING HIGH RESOLUTION SEDIMENTARY FACIES PREDICTION OF ABU GHARADIG PERICRATONIC BASIN OF THE NORTH WESTERN DESERT, EGYPT AND ITS HYDROCARBON HABITAT
}

\author{
Sahar Hassan, S. ${ }^{1}$ and Darwish, M. $^{2}$ \\ 1- Ex-Schlumberger-Reservoir Characterization Group. saharshaaban@gstd.sci.cu.edu.eg \\ 2- Geology Department, Faculty of Sciences, Cairo University. mohameddarwish@sci.cu.edu.eg
}

\begin{abstract}
The Upper Cretaceous sequences of the north Western Desert of Egypt form the main hydrocarbonbearing sequences of the mature petroleum system in the pericratonic Abu Gharadig basin. One of the main targets is the sandstone-dominated Bahariya Formation of Late Albian-Early Cenomanian age. It overlies unconformably the Middle to Lower Albian fluvial-dominated sandstones of the Kharita Formation. The boundary between these two rock units (of different facies types) is actually difficult to be detected, using the limited conventional wireline logs. Certainly, the application of the high-resolution analyses; palyno-biostratigraphic, formation micro-images lithofacies extraction and core data, in addition to the different conventional wireline logs, supported the ability to differentiate and predict the important and lithologically obscured boundary between the Bahariya and the Kharita formations.

The Bahariya Formation is distinguished into five depositional sequences (1 to 5), from bottom to top, in the selected four wells. The depositional sequence boundaries were identified lithologically by a basal mudstone facies (sequences 1, 3, $4 \& 5$ ), with the exception of a pronounced lime-muddy facies at the base of sequence no. 2. The lowermost sequence represents mixed flat facies, followed upwardly by sandstone-dominated tidal channels, accompanying the global sea level rise, and ended with a shallow marine carbonate bed. The second sequence starts at the base with sand-dominated mixed flat deposits denoting the early lowstand systems tracts of the next sea level rise, followed by shelfal mudstone facies. A non-depositional gap that supported by the presence of a hard ground terminated this sequence. The third cycle starts with the flooding event represented by mudstone and shaly facies, followed upward by a continuous sea level rise building vertically stacked shoreface facies and forming an offshore sandbar. The fourth sequence reflects relatively a sea-level fall and composed of a mixed flat, that intersected by tidal channels and creeks, and topped by shallow subtidal sediments. The fifth sequence begins with a repeated sandy mixed flat that affected by storm events resulted in the deposition of tempestites and lower shoreface facies (trough and hummocky cross stratifications, in addition to glauconitic sandstone facies) and ended up with the shallow subtidal carbonate facies at the base of Abu Roash Formation (Upper Cenomanian).
\end{abstract}

The development of shoreface sandy facies of the sequences three and five represents the maximum rate of sea level rise, developing the offshore sand bar system. These bars, due to sea level rise events, represent the high-quality sandstone reservoirs, in addition to the tidal channels, that may represent a moderate to high-quality reservoir.

Keywords: Abu Gharadig basin, Bahariya Formation, Albian-Cenomanian, Formation MicroImager, Electrofacies, depositional sequences, Palyno-biostratigraphy.

\section{INTRODUCTION}

The north Western Desert province has been extensively explored by many international and national companies targeting the Mesozoic reservoir formations (Ras Qattara, Khatatba, Alam El Buieb, Kharita, Bahariya and Abu Roash). The simple, monotonous, and almost flat regional extending surface geological features of the Northern Western Desert, become exceedingly complicated in the subsurface (Hantar, 


\section{Hassan and Darwish}

1990). The global plate tectonics and eustacy are the main factors that control the sedimentary rift basins configuration within the North Western Desert. The north Western Desert consists of eight sedimentary basins (Moustafa 2008) where the largest one is the pericratonic Abu Gharadig basin which shows three main fault systems WNW- ESE, E - W and NE - SW (Meshref 1990 and Darwish and Tewfik 2008).

The study area is located in the north-central part of Abu Gharadig basin between Longs. $27^{\circ}-29^{\circ} \mathrm{E}$ and Lats. $29^{\circ}-31^{\circ} \mathrm{N}$ (Fig. 1). The primary target in the study area is the oil-bearing Bahariya Formation, which consists of sequences of sandstone, siltstone and claystone facies (Fig. 2). Many disciplines and methods of the reservoir characterization evaluation are known and applied. One of them is the petrophysical evaluation which has limitations to identify very thin layers, detect the sedimentary structures and its orientation. Borehole imaging technology introduced to the oil industry to enhance the reservoir evaluation from a geological point of view (Lagraba et al. 2010). Four wells have FMI data that are the milestone in the evaluation of the present study.

Fig. 1: Egypt's main petroleum basins and structure map for the study area modified after (Dolson et al. 2014), (El Redini, et al 2017).
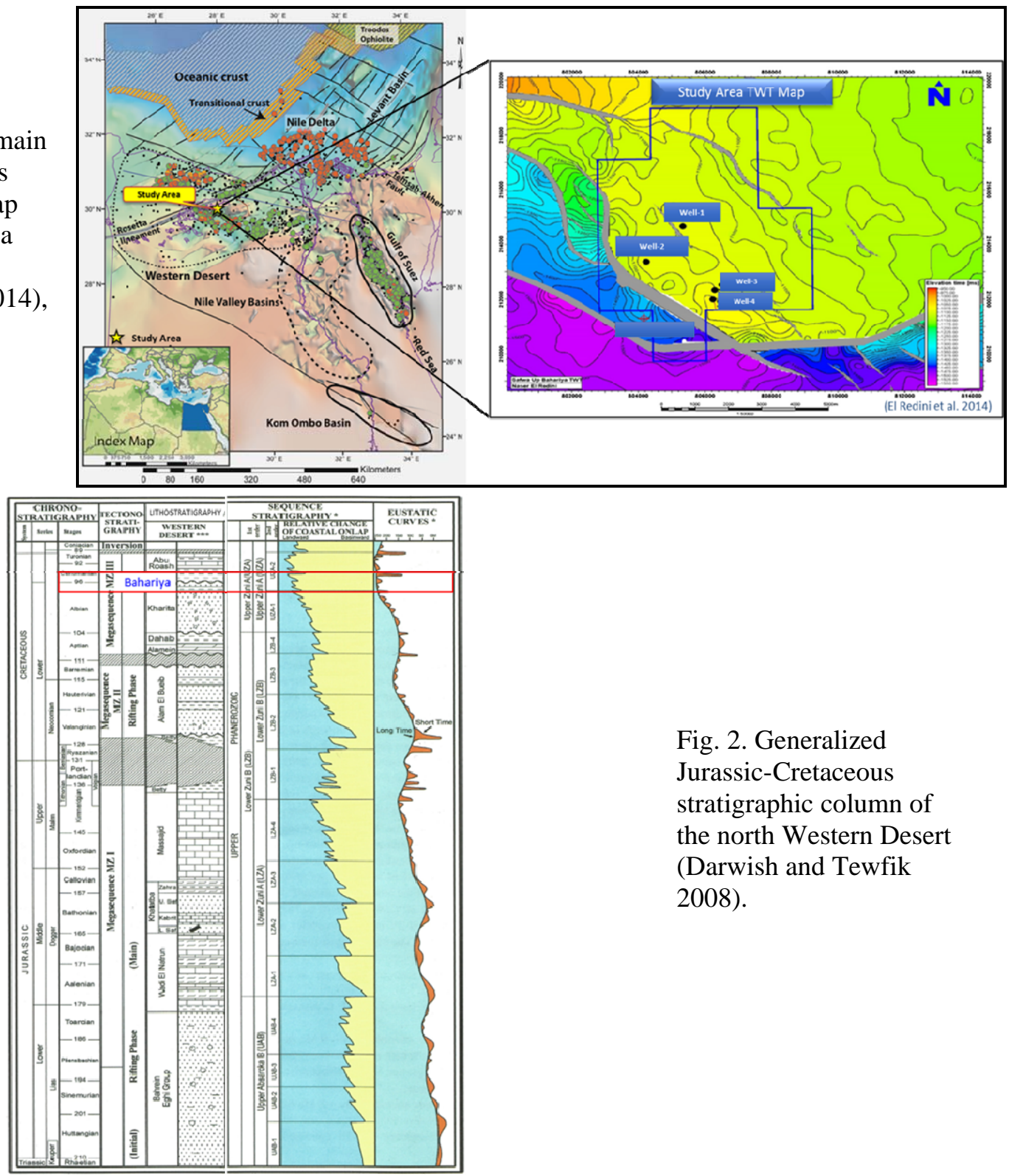

Fig. 2. Generalized Jurassic-Cretaceous stratigraphic column of the north Western Desert (Darwish and Tewfik 2008). 
Late Albian - Early Cenomanian Basin evolution

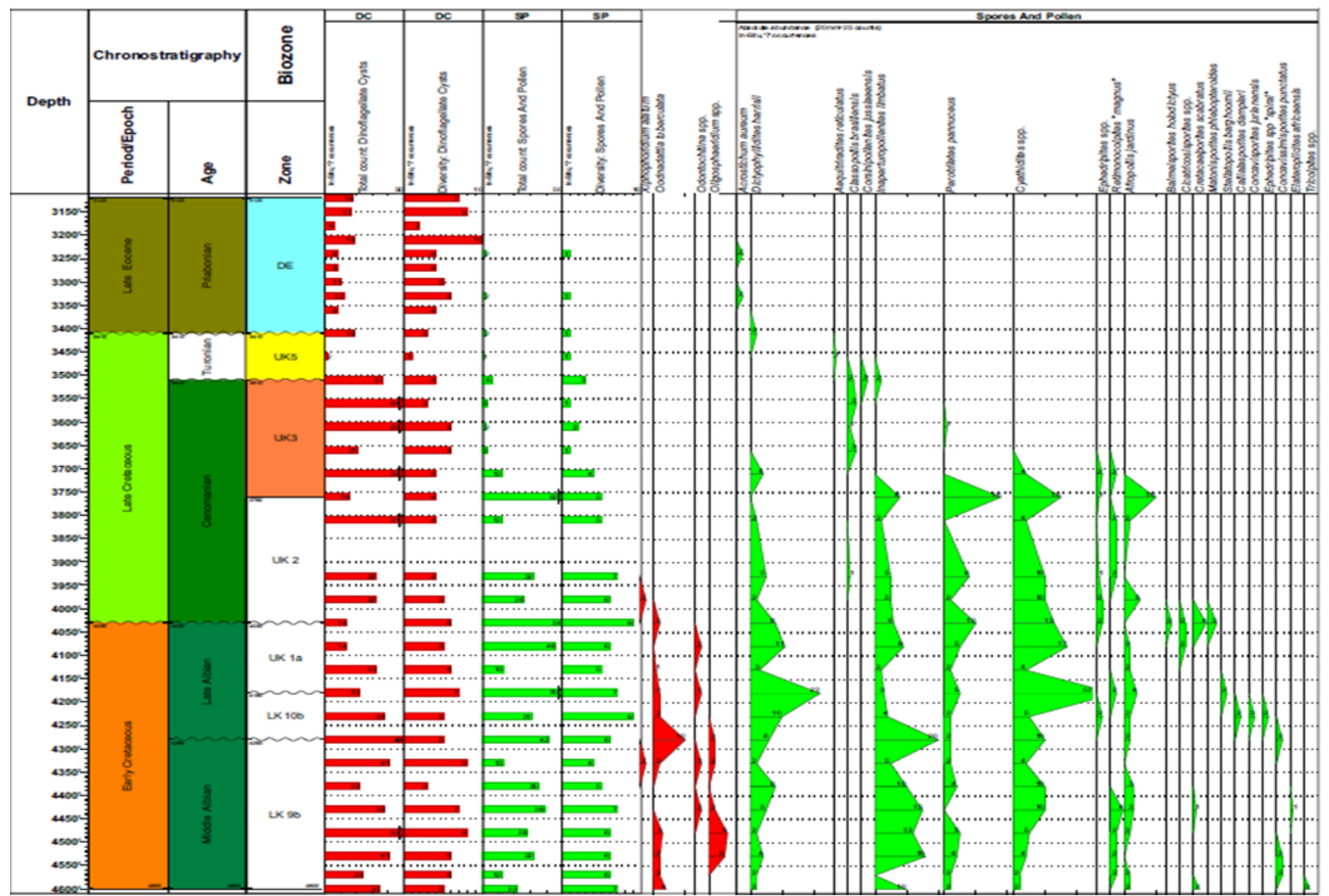

Fig. 3: Palyno-chronostratigraphic chart showing the main depositional sequence boundaries based on the first downhole appearance of palynomorphs.

\section{METHODOLOGY}

The palyno-chronostratigraphic analysis results have been used to identify precisely the Bahariya Formation age in the study area, as many authors put it as mainly Early Cenomanian (i.e. Dominik 1985, Taher, Said, and T. 1988, El Toukhy and Bakry 1988, Wali and Ayyad 1988, Hermina, Klitzsch, and List 1989, Hataba and Ammar 1990, and Darwish, 1994) . In the study wells, the palyno-chronostratigraphic results approved that the Bahariya Formation age is Late Albian to Early Cenomanian, which matching with a number of studies (i.e. Conway et al. 1988, Sultan \& Halim 1988, B U Haq, Hardenbol, and Vail 1988 Taha \& Halim 1990 and Darwish 1994). In the selected wells the palynostratigraphic analysis of the ditch cuttings supports that the Bahariya Formation is considered as diachronous ranging in age from Late Albian to Early Cenomanian proved by the present identified unique palynmorph assemblages (Fig. 3).

The borehole imaging technology started since 1945 begins with a three-arm dipmeter tool, then HDT (High-Resolution Dipmeter Tool) till reaching the high-resolution borehole imaging tool (Full-bore Formation Micro Imager) in 1992 and QuantaGeo in 2014 (Lagraba et al. 2010). The borehole imaging technology is one of the fastest and most precise methods for collecting subsurface data. In addition to core photographs and biostratigraphic analyses for conventional cores and ditch cuttings, a high-resolution depositional model has been predicted and interpreted. The main workflow that used in the present evaluation is displayed in (Fig. 4). Borehole image processing is divided into five steps: data loading, inclinometry quality control, speed correction, array processing, and image creation (normalization) and interpretation (Fig. 5). The interpretation includes sedimentary structures identification, structural dip analysis, and clastics texture analyses in addition to electrofacies extraction. Integration between the sedimentary structures, FMI-extracted electrofacies with wireline logs (density, neutron, and photoelectric effect), the core photographs and biostratigraphic data lead to the prediction of the high resolution schematic depositional model. The main used dip scheme in the FMI analysis is displayed in (Fig. 6). 
Hassan and Darwish

Fig. 4: The Present study workflow.
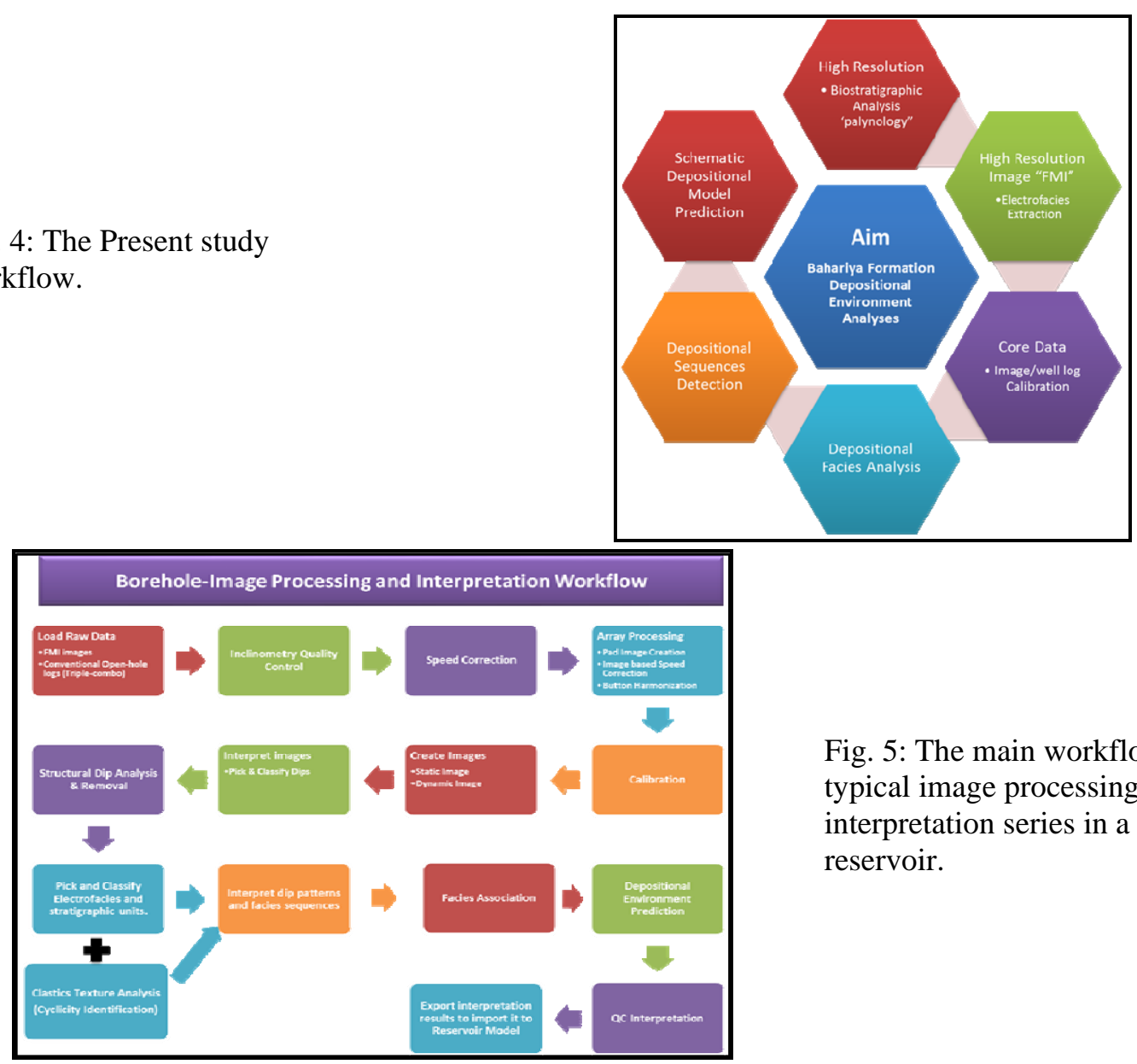

\begin{tabular}{|c|c|c|}
\hline Feature Name & Description & Symbol \\
\hline Bed bound ary & $\begin{array}{l}\text { Planar, continuous feature reflecting concordant lithology and } \\
\text { representing a bed boundary within shale and carbonate units. }\end{array}$ & e \\
\hline $\begin{array}{l}\text { Linconformable } \\
\text { bed boundary }\end{array}$ & $\begin{array}{l}\text { A boundry that lies uncomfortably with the boundaries } \\
\text { above below, it could be associated with an abrupt change in dip } \\
\text { angle or lithology with no gradual or sedimentological relationship. }\end{array}$ & \\
\hline $\begin{array}{c}\text { Coset } \\
\text { Boundary }\end{array}$ & $\begin{array}{l}\text { Low ande bed boundry that marks the end of a set of cross bedded } \\
\text { sands and the beginning of a new set. }\end{array}$ & \\
\hline Cross bedding & $\begin{array}{l}\text { These dips represent the high an gle bedding obser ed in sand } \\
\text { lithology that is might be coulsed by currentflow: }\end{array}$ & \\
\hline $\begin{array}{l}\text { Laminated } \\
\text { Sandstone }\end{array}$ & Iow dip horizontal laminations within sandstone sections & \\
\hline $\begin{array}{c}\text { Cross } \\
\text { Laminations }\end{array}$ & $\begin{array}{l}\text { The pattern of lamination mithin sands that dereloped as a result of } \\
\text { the migration of ripples andit is in cm scale }<5 \mathrm{~cm}\end{array}$ & \\
\hline Ripples & High angle climbing features within sand unit & \\
\hline $\begin{array}{l}\text { Laminated } \\
\text { Siltstone }\end{array}$ & Iow dip horizontal laminations within siltstone sections & \\
\hline Heterolith ics & Thinly (cm-scale) shale, silt and sand interlamination. & \\
\hline Flaser Bedding & $\begin{array}{l}\text { Cross laminated sand contains mud streaks or laminated mud } \\
\text { contrins pockets of cross laminated sands. }\end{array}$ & \\
\hline Minor Fault & Continuous planar feature cutting bedding with sense of off set. & \\
\hline $\begin{array}{l}\text { Truncation } \\
\text { Surface }\end{array}$ & $\begin{array}{l}\text { Tsually related to coarse grained deposits cutting into finer grained } \\
\text { deposits. In sand this could indicate a scour surface due to the coset } \\
\text { of aur ent flow: }\end{array}$ & \\
\hline $\begin{array}{l}\text { Reactivation } \\
\text { Surface }\end{array}$ & $\begin{array}{l}\text { A small erosional surface that sep arates two flows within a channel. } \\
\text { It indicates a change in flow dynamics. }\end{array}$ & \\
\hline Deformed bed & A deformed bed boundary due to faulting, slumping, loading etc. & \\
\hline $\begin{array}{l}\text { Deformed } \\
\text { Sand }\end{array}$ & $\begin{array}{l}\text { Deformed sand beds due to faulting, slumping or loading and are } \\
\text { of ten accomp anied by mud clasts }\end{array}$ & $\nabla$ \\
\hline Breakout & $\begin{array}{l}\text { Tide, linear feature imrolving the crumbling of the borehole wall } \\
\text { due to mud weight and rock compressive strength falling below the } \\
\text { minimum horizontel stress. }\end{array}$ & (U) \\
\hline
\end{tabular}

Fig. 6: Dip identification scheme.

Fig. 5: The main workflow steps for a typical image processing and interpretation series in a clastic reservoir. 
Late Albian - Early Cenomanian Basin evolution

\section{IMAGE ANALYSIS AND INTERPRETATION}

\section{Sedimentary Structures Identification}

Borehole image interpretation started with the manual dip picking step that includes the identification, classification, and interpretation of any planar sedimentary or structural features. In the study area, the borehole image covers most of the borehole similar to an unslabbed core photograph. The main identified sedimentary structures are: lamination, cross lamination, cross-bedding, flaser/lenticular bedding sandstone, laminated siltstone, laminated claystone, heterolithics, erosive/ reactivation surfaces and deformed sandstone/mudstone (Fig. 6). An example from the FMI image is summarized in (Fig. 7).

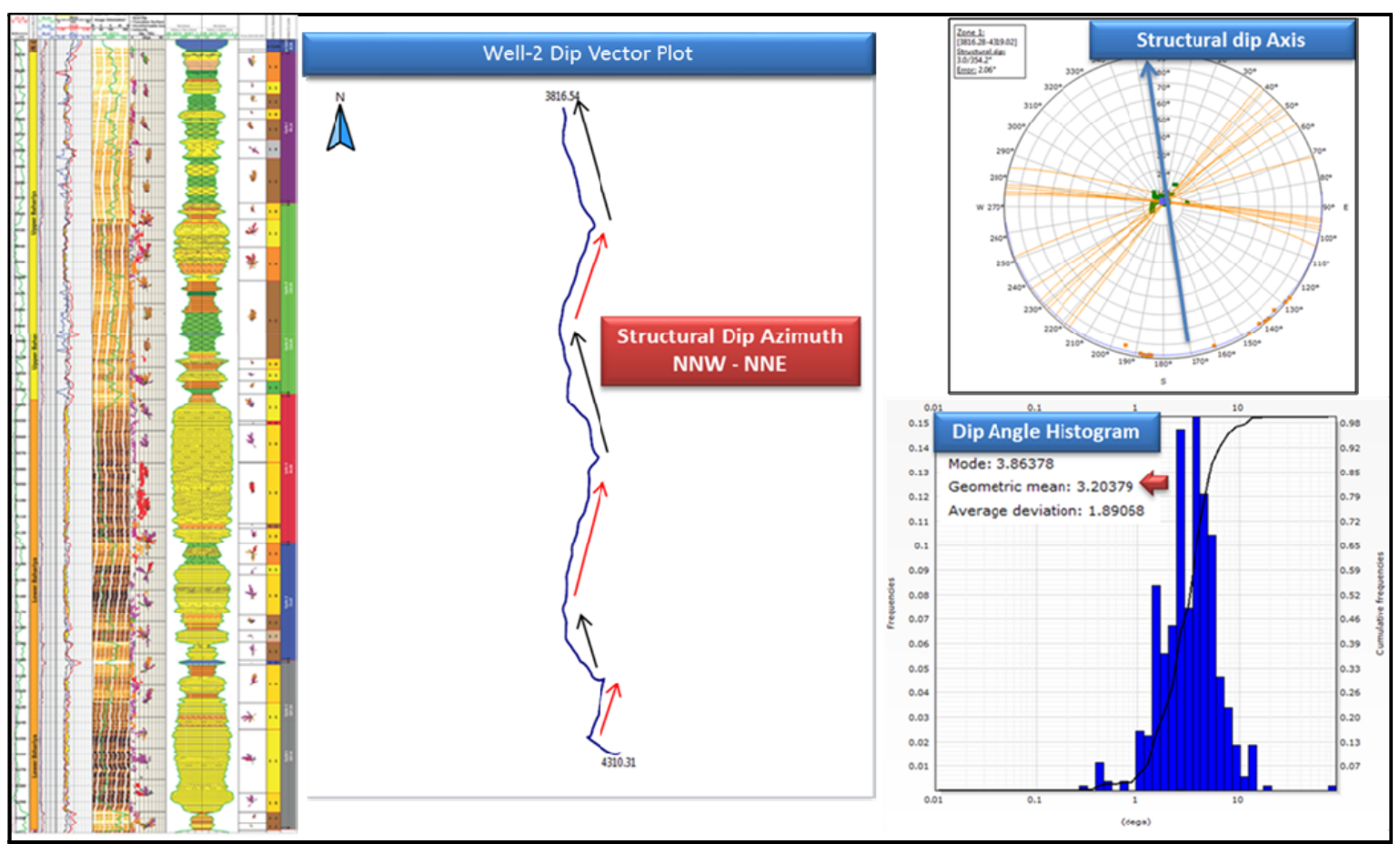

Fig. 7: Structural dip-azimuths of well-2 that show the dominant dip azimuth trends toward the NNW and low dip magnitude, that is clarified in the dip angle histogram and showed geometrical mean dip $3.2^{\circ}$ that represents average dip for the horizontally deposited sediments.

\section{Structural Dip Analysis}

The structural dip is generally defined from the beddings in lithologies that are assumed to have been deposited with horizontal or near-horizontal attitudes, such as mudstone and heterolithics zones in the study area. The study intervals within the selected wells show low structural dip range $\left(2^{\circ}-5^{\circ}\right)$ and didn't need any further structural dip removal process (Figs. 6 \& 7).

\section{Electrofacies Extraction}

The milestone of the facies interpretation is to integrate the observations made on their spatial relations and internal characteristics (lithology and sedimentary structures) with comparative information from other well-studied stratigraphic units and particularly from studies of modern sedimentary environments. Sedimentary facies term has been adapted in sedimentology to distinguish between sedimentary rocks which differ in appearance and have formed in different ways. In the present study, twenty-seven electrofacies have been identified based on the integration between images, core photographs and wireline logs. The main identified lithofacies are massive, laminated, cross-bedded, cross-laminated, flaser/lenticular bedded and convolute bedded sandstone facies, in addition to the massive and laminated claystone and siltstone facies. The limited presence of carbonate facies, glauconitic bioturbated sandstone, and bioturbated claystone, and siltstone facies are identified in (Fig. 8). 


\section{Hassan and Darwish}

\section{Facies Association Prediction}

The detailed facies analysis of the Bahariya Formation in the study area revealed the dominance of marginal to shallow marine siliciclastic sequences, with few carbonate interbeds. The sequence of the different types of the extracted electrofacies forms a facies association which reflects the depositional suite. Eleven facies associations have been interpreted based on the integrating of the twenty-seven electrofacies extracted from the FMI images, wireline logs, and core photographs, as followed from the shallow landward to partly open basinward.

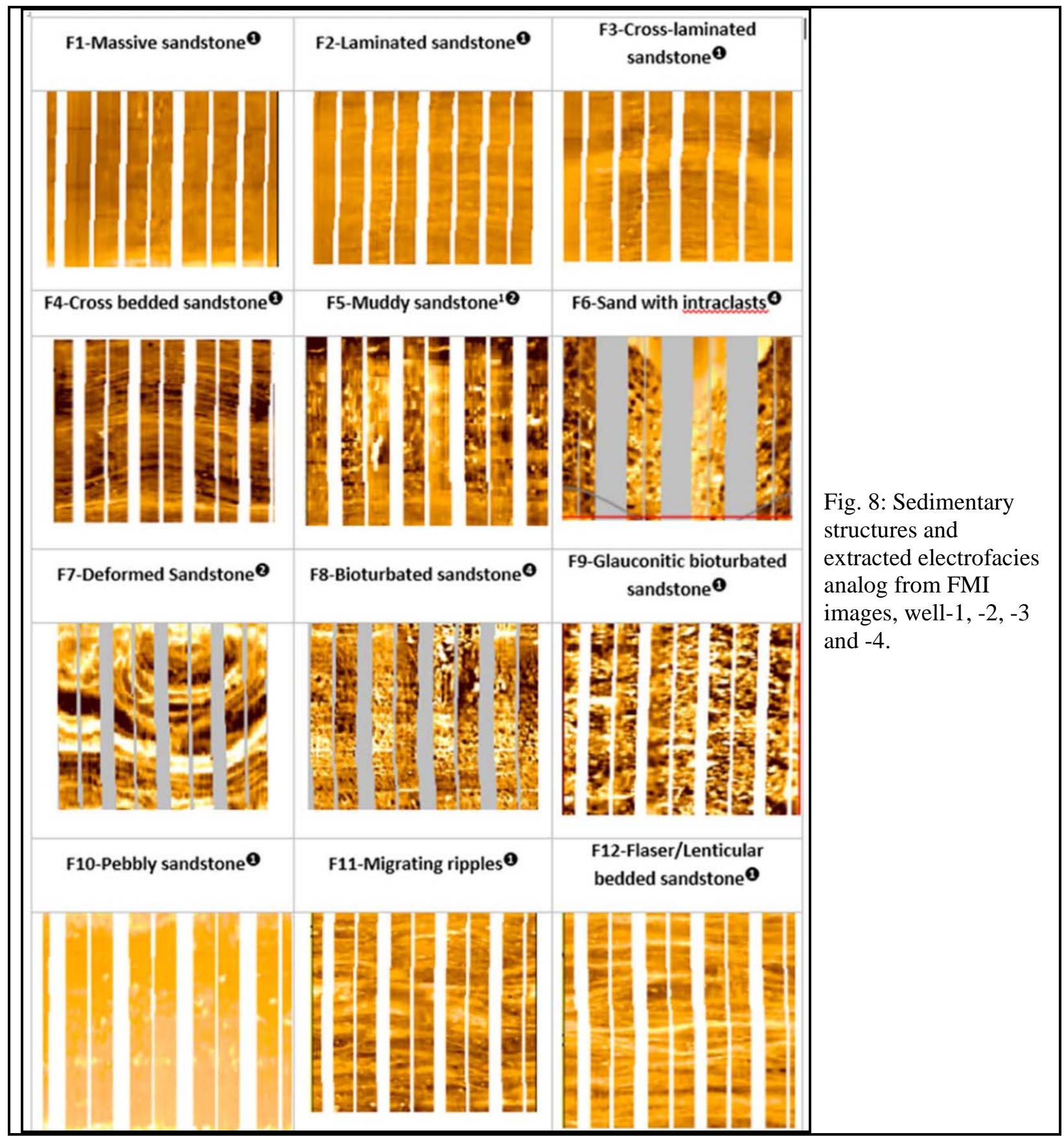


Late Albian - Early Cenomanian Basin evolution

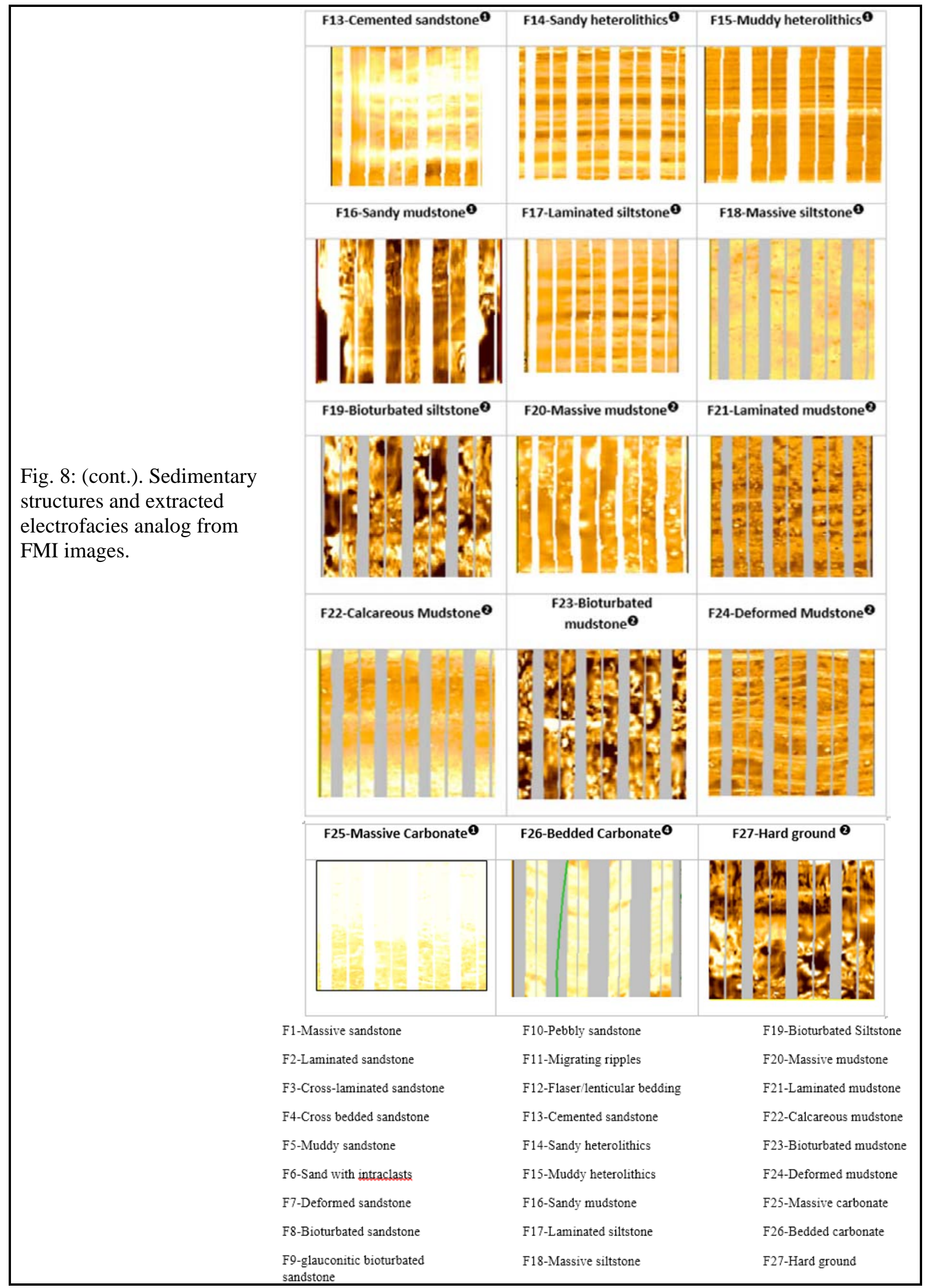




\section{Hassan and Darwish}

\section{BAHARIYA FORMATION DEPOSITIONAL SEQUENCES}

The Upper Albian - Lower Cenomanian Bahariya Formation in the present work is divided into five depositional sequences, where each sequence consists of a group of parasequences. Every facies association is composed of a number lithofacies (Table 1). The depositional sequences one and two are subdivided into three parasequences per each, while the sequences four and five are distinguished into four parasequences per each, and the sequence three includes two parasequences. The detailed description for each sequence and parasequence is presented in the following section.

Based on Haq (2014), the cyclicity patterns of the Upper Albian- Lower Cenomanian sequences (KAl 6, $\mathrm{KAl} \mathrm{7,} \mathrm{KAl} \mathrm{8,} \mathrm{KCe} \mathrm{1,} \mathrm{and} \mathrm{KCe} 2$ ) have been applied in the study area and supported by the palynological results of the study wells (Figs. 9 to 14).

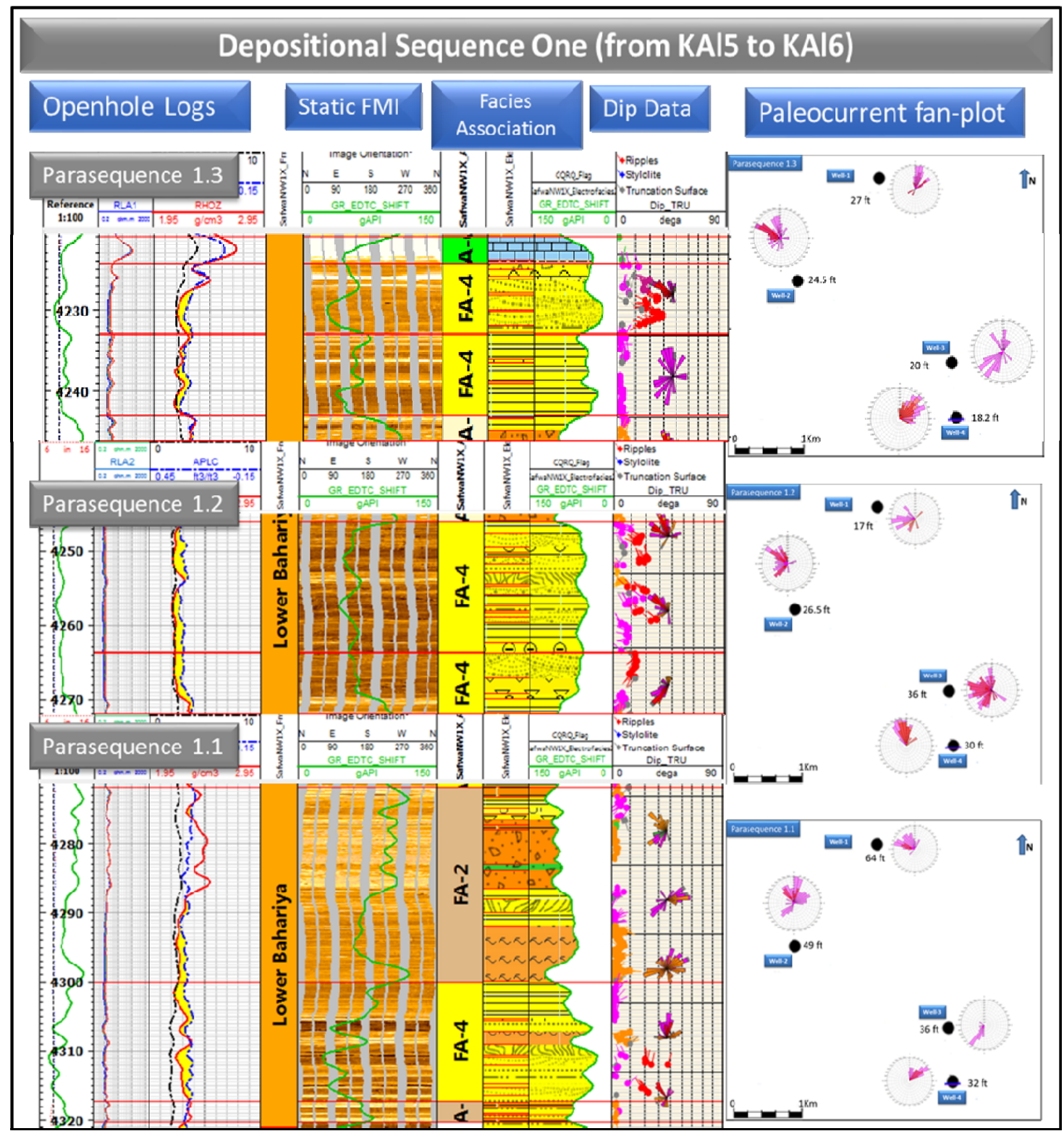

Fig. 9: Depositional sequence one deposits examples from the studied wells show that the lowermost parasequence built up of mixed flat deposits that followed by tidal inlet deposits of multiple tidal channels and topped by the foreshore lime mudstone. 
Late Albian - Early Cenomanian Basin evolution

Table 1. Facies and Facies Associations

\begin{tabular}{|c|c|c|}
\hline$\#$ & Facies Association & Characteristic Facies \\
\hline FA-1 & Mud Flat & F20- F21 \\
\hline FA-2 & Mixed Flat & F5- F14-F15-F17-F18-F25 \\
\hline FA-3 & Sand Flat & F2-F5-F12 \\
\hline FA-4 & Tidal Channel & F1-F2-F4-F6-F7-F11-F12 \\
\hline FA-5 & Tidal Creek & F2- F3 \\
\hline FA-6 & Foreshore/Subtidal deposits & F8-F25-F26 \\
\hline FA-7 & Upper Shoreface & F2-F4-F6 \\
\hline FA-8 & Lower Shoreface & F2-F3-F5-F9-F10 \\
\hline FA-9 & Tempestites & F9-F10 \\
\hline FA-10 & Washover & F1-F2 \\
\hline FA-11 & Basinal Mudstone & F18-F20 - F21 \\
\hline
\end{tabular}

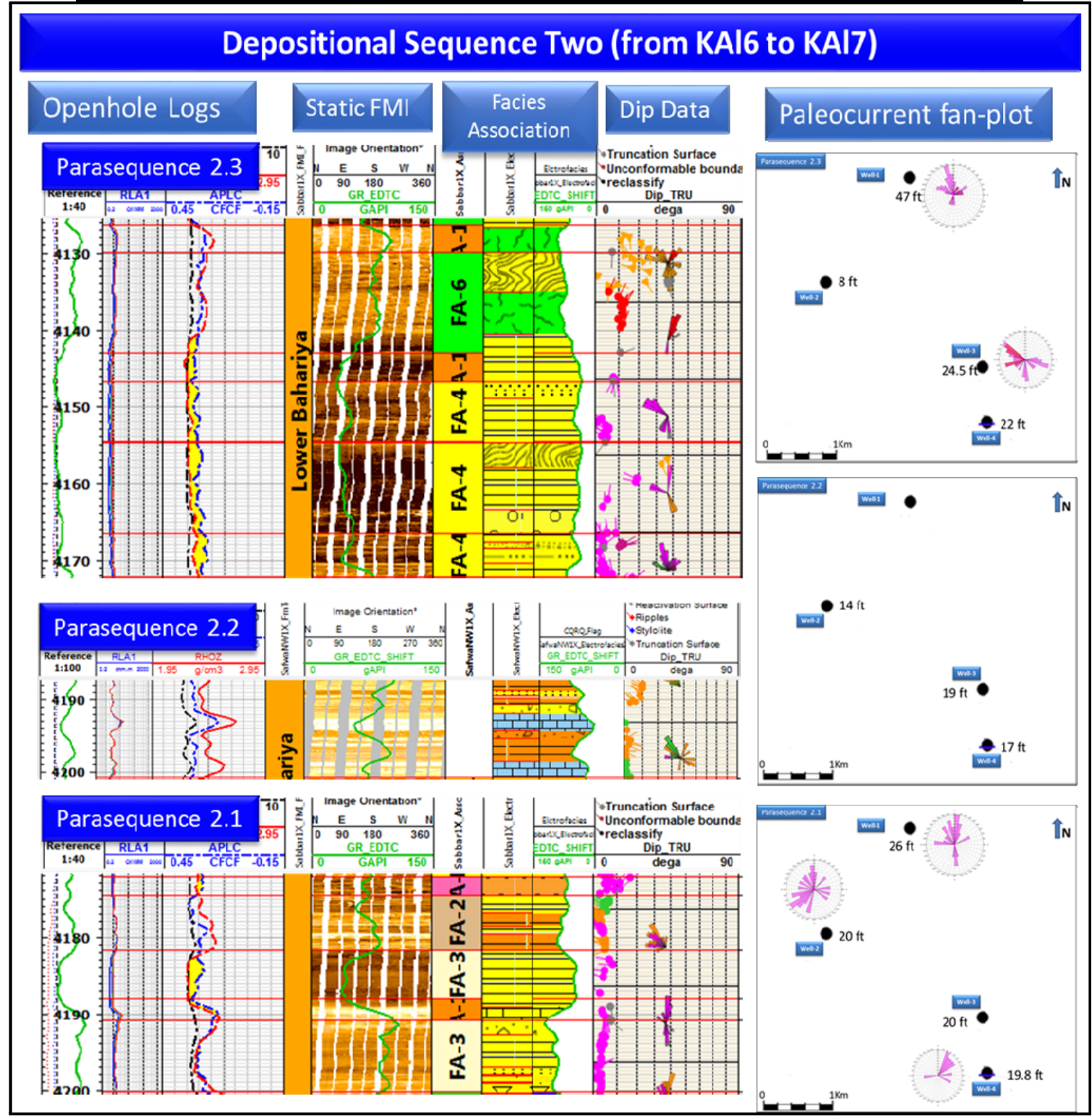

Fig. 10. Depositional sequence two facies and facies association with dip data and fan plots of the main trends of paleocurrent. 
Hassan and Darwish

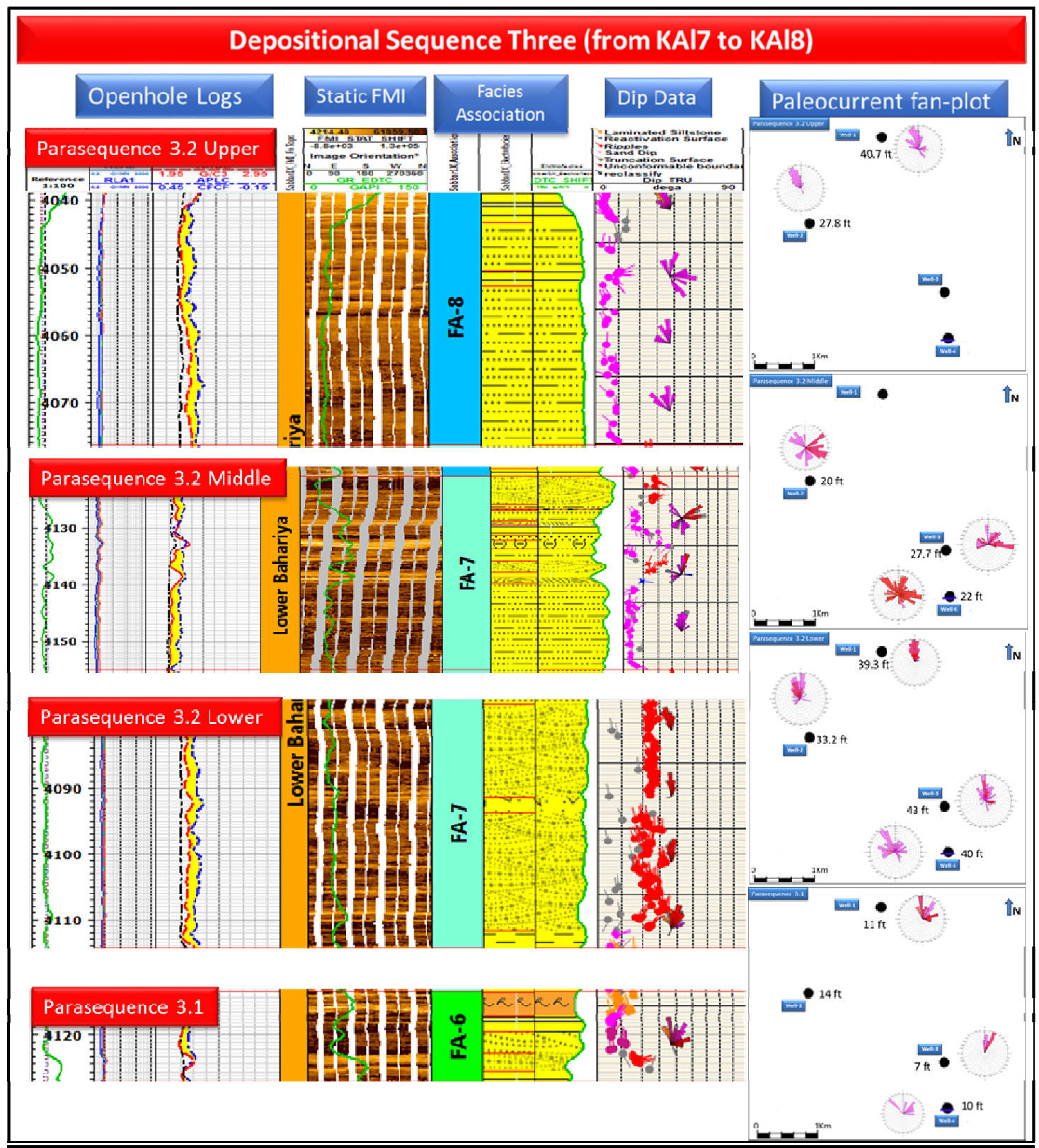

Fig. 11. The dip orientation of the parasequences of depositional sequence three that show the dominant trends toward the north with subordinate NE and ENE.

\section{Sequence (1): Intertidal to subtidal facies dominated (KAl 6)}

It is recorded throughout the entire study area, where its lower boundary is the (SB1) Kharita/ Bahariya, while the top boundary is the foreshore carbonate bed observed all over the study area (Fig. 9). The top boundary is confirmed by the first appearance of certain palynomorphs (Callialasporites dampieri/ Concavissimisporites puncatatus) in well-2 and well-3, while (Ephedripites spp "spiral"/ Concavisporites jurienensis/ Oligosphaeridium spp) is appeared only in well-2 and (Camarozonosporites insignis /Spore type Q/ Systematophora silyba) appeared only in well-3. According to the latest chronostratigraphic chart (Bilal U. Haq, 2014), this boundary matching the "KAl6" boundary and represented by dashed blue line (Fig. 14). The first sequence is subdivided into three parasequences representing a relative transgressive depositional sequence (from bottom to top): 
Late Albian - Early Cenomanian Basin evolution

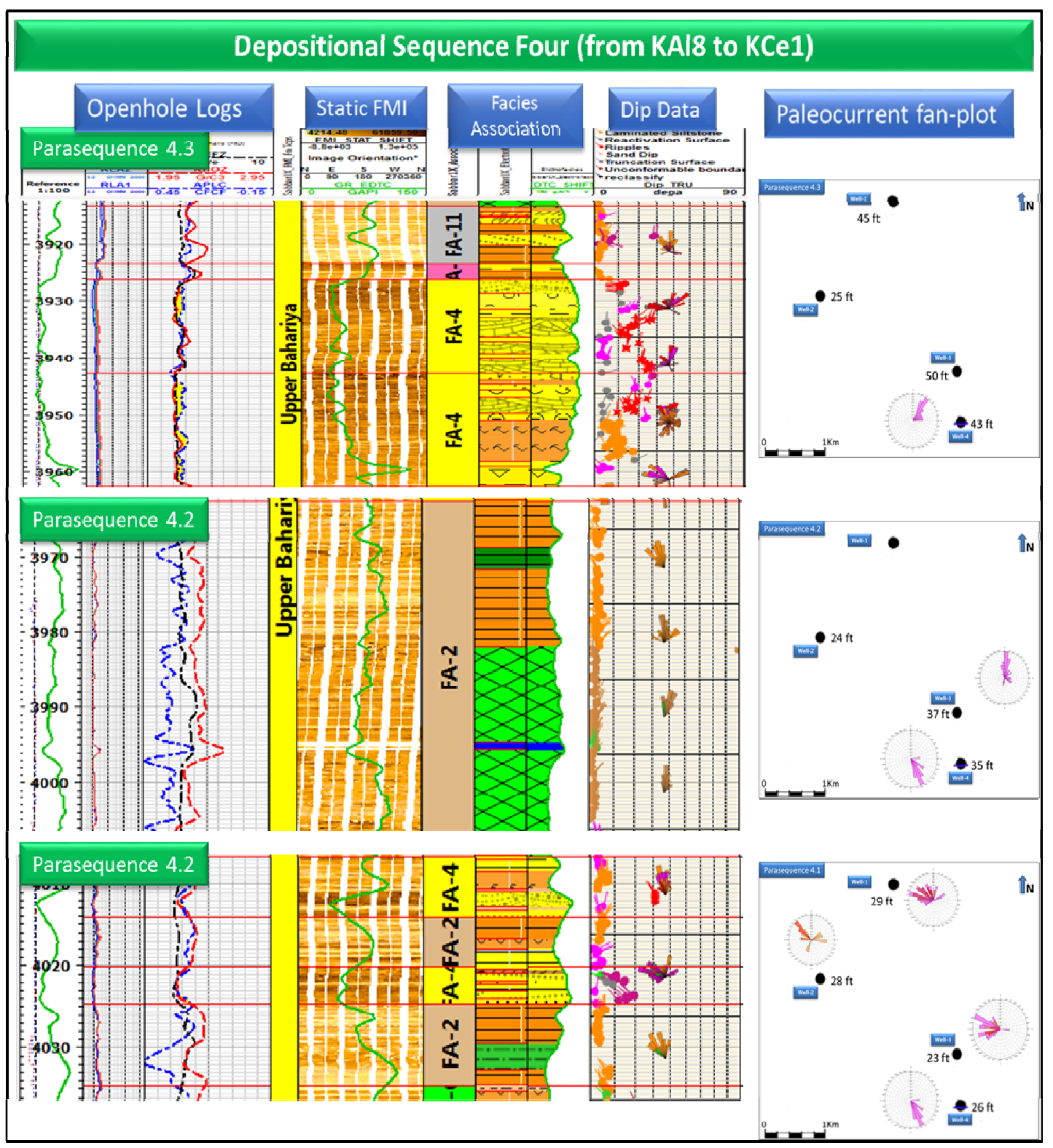

Fig. 12. The dip orientation of the three parasequences of the depositional sequence four that show the dominant trends toward NW, NNW and subordinate NE while syndepositional deformation only in well-4.

Parasequence 1.1: It is built-up of laminated claystone and siltstone facies with average dip $\left(\sim 3^{\circ}\right)$, that deposited mainly from suspension and low energy flow, showing dip azimuth swinging from NW to NNE. It has been intersected by some distributaries of high energy deposits of a tidal channel (laminated and cross-bedded sandstone), with the limited presence of flaser and lenticular bedded sandstone and bioturbated siltstone, with dominant flow direction towards the NNW trend. This sub-cycle represents the lowstand systems tracts that followed by high energy deposits of cumulative tidal channel deposits (Fig. 9).

Parasequence 1.2: It is composed mainly of multiple reactivation surfaces that filled with pebbly sandstone, followed by cross-bedded and laminated sandstone facies. Laminated siltstone facies is recorded only at the top of well-4. A channelized activity, with SW dip azimuth trend has been observed in wells-1,-2 and -3 of flood direction and the ebb direction recorded only in well-4 "NNW". This thick sandstone facies has been deposited mainly during the transgressive systems tract stage (Fig. 9). 


\section{Hassan and Darwish}

Parasequence 1.3: It represents a continuous development of channelized sandstone deposits that overlapped by the fine-grained deposits (laminated, massive siltstone and carbonate facies) of a subtidal depositional suite (Figs. 8 and 9) which represents the maximum flooding recorded event within this cycle (Fig. 9).

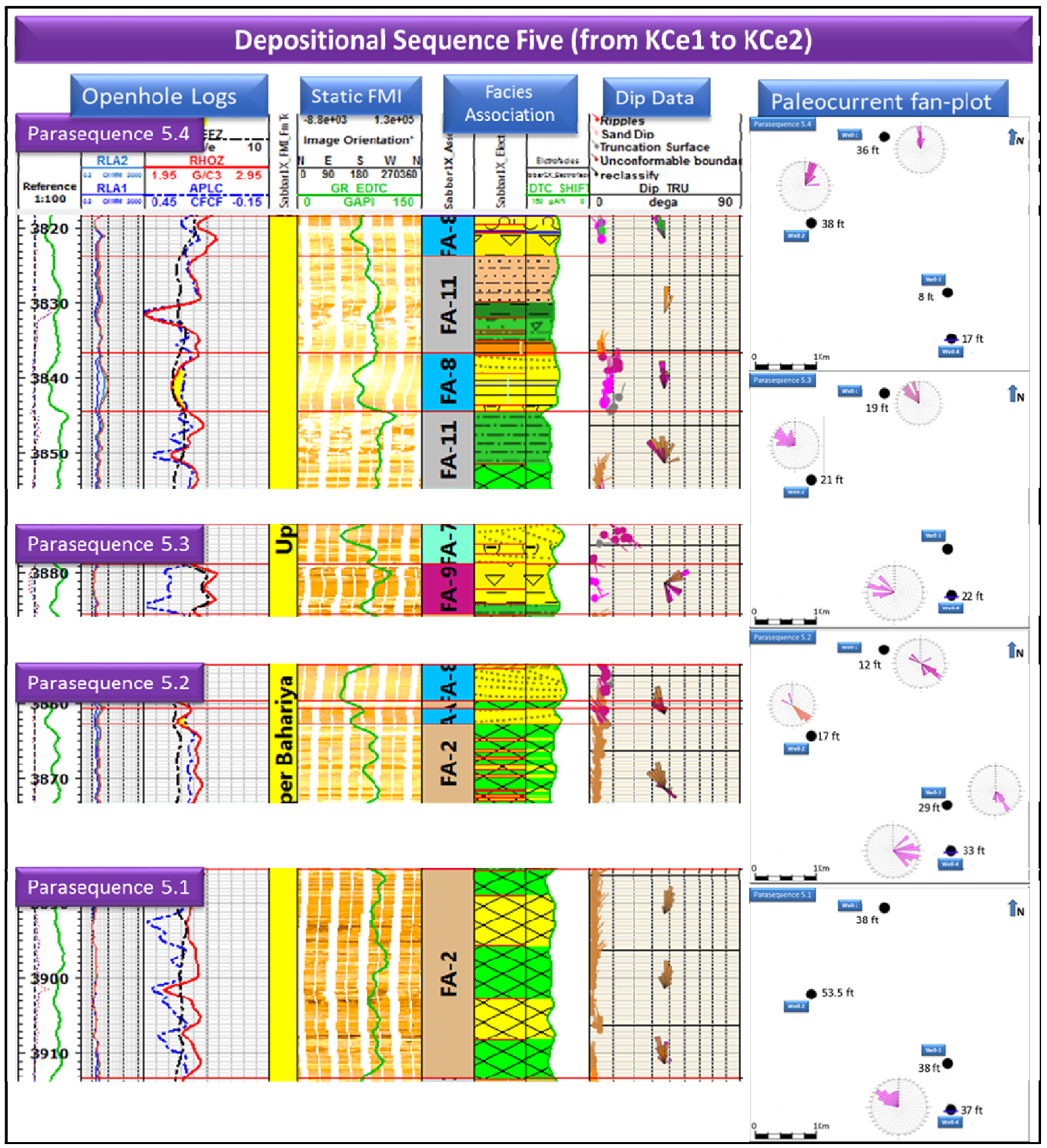

Fig. 13. The depositional sequence five and its four parasequences with the dip orientation that show the dominant trends toward NNW with subordinate SE.

\section{Sequence (2): Intertidal to subtidal facies dominated (KAl 7)}

It reveals a second transgressive cycle that started with lowstand intertidal fine-grained deposits overlapped with tidal channel facies and in some parts mixed flat deposits. The lower boundary is 


\section{Late Albian - Early Cenomanian Basin evolution}

equivalent to the "KAl 6", while the upper boundary "KAl 7" has been approved by the first downhole appearance of palynomorphs (Fig. 3). It is characterized by the first appearance of the palynomorphs (Stellatopollis barghoomii) in well-2 and -3, (Ephedripites type-1 "spiral") in well-1 and - 3, (Elaterosporites verrucatus) only in well-1, which is equivalent to the updated biochronostratigraphic chart of El Haq (Bilal U. Haq, 2014). The upper boundary is characterized by a depositional gap in wells 2,-3 and -4 , and preserved hard ground in well- 1 and approved by the presence of subtidal mudstone facies with NW trend that topped by SW dipping foreshore deposits of sequence three. This sequence is differentiated into three parasequences, as follows:

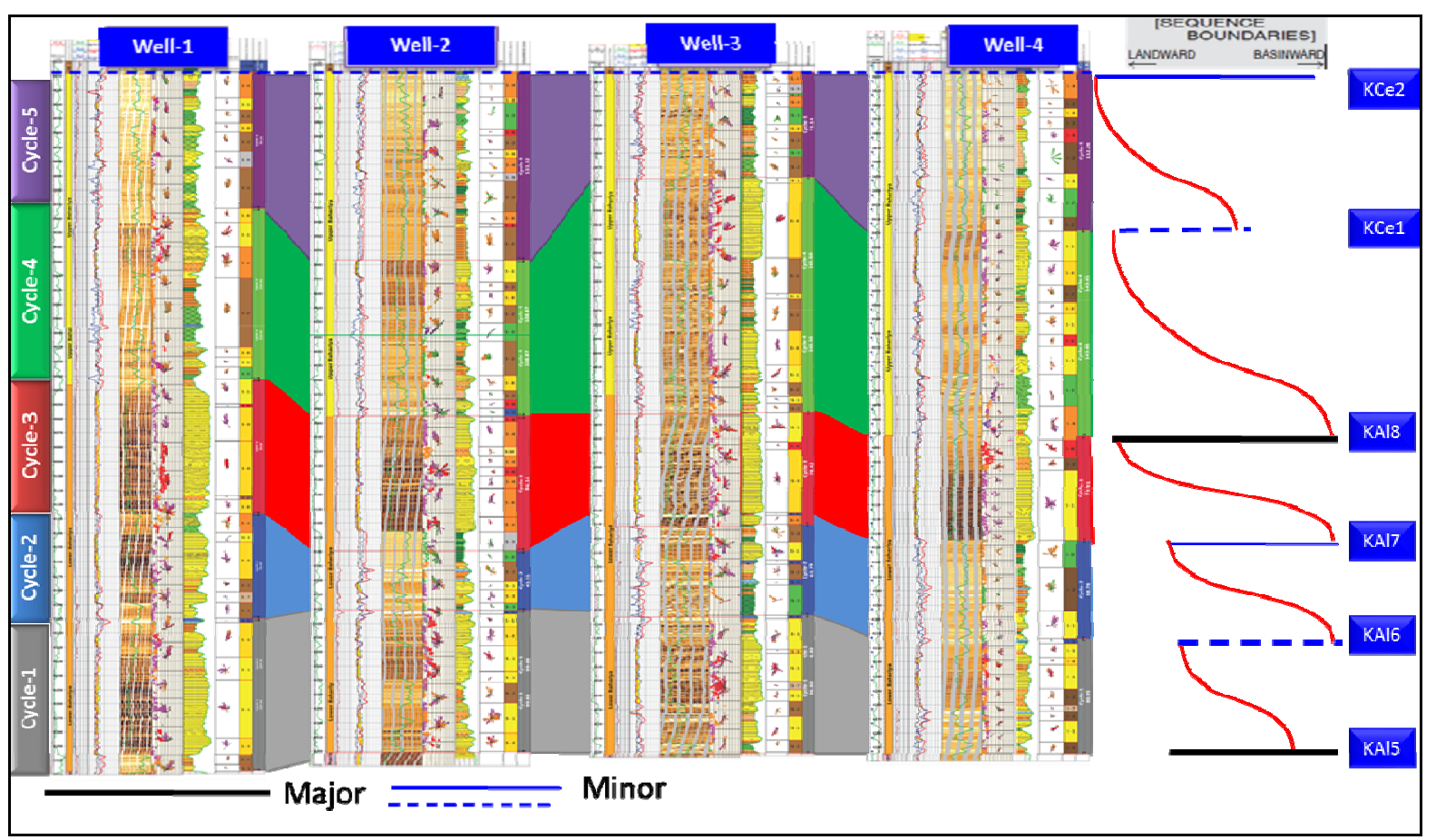

Fig. 14. Correlation between the studied four wells and the palyno- chronostratigraphic based sequences boundaries after (Haq 2014)

Parasequence 2.1: It is composed of massive and laminated mudstone, and siltstone with muddy sandstone facies. The presence of bioturbated siltstone/sandstone facies of mixed flat to mudflat deposits is Limited. It is dissected by a channelized sandstone deposits in well-2, with NNW dip azimuth trend. The dip magnitude of the fine-grained deposits is $\left(3^{\circ}-5^{\circ}\right)$. The sediments are mainly were deposited in a mixed flat suite (Figure 10). It represents a lowstand systems tract (LST) stage of this sequence.

Parasequence 2.2: It is composed mainly of interbeds of laminated siltstone and claystone, with two carbonate streaks. The dip data are dominated by the NW dip azimuth trend respectively in wells- $1,-3$ and -4. It is deposited from relatively lower flow regime, compared to the underlying parasequence (Figure 10). It represents a transgressive systems tract (TST) of this sequence.

Parasequence 2.3: It is built-up of vertically stacked sandstone facies in wells -1,-2and -3 and laterally changed to mixed flat deposits in well-4. It is dominated by laminated, cross-bedded, massive and pebbly sandstone facies. The dip data are dominantly towards the NW with subordinates to the NNE, SSW, and ESE. The cross-bedded sandstone angle is increased from $5^{\circ}$ up to $22^{\circ}$ in well-3 and decreased again to $5^{\circ}$, and associated with the upward shift in dip azimuth from SW to NW. It is overlapped with more transgressive deposits; laminated claystone with streaks of siltstone and deformed mudstone facies that dominated by swinging dip azimuth from NW to NE trends. Those fine-grained deposits of subtidal zone represent the maximum transgressive (MFS) stage within this sequence. 


\section{Hassan and Darwish}

\section{Depositional Sequence (3): Offshore Bar (KAl 8)}

It is considered as the maximum marine transgression event recorded within the study area, over the interval of interest, following the underlying tidal system of sub-environments. It starts with claystone bed that recorded in all the wells, but with different thicknesses where the main dip azimuth is toward the SW direction. These claystone facies are overlain by a thick sandstone body in the entire study area that consist of laminated, trough cross-bedded, with intraclasts and cross-laminated facies. Glauconitic sandstone facies has been recorded within wells- 1 and -2 . Flaser bedded sandstone facies are recorded in wells-1 and -4. The trough cross-bedded sandstone facies shows the largest thickness within well-2, with NNW dip azimuth, as a dominant trend for the entire sand body. The lower boundary (SB) is characterized by a depositional gap associated with the missing of highstand systems tract (HST) deposits of depositional sequence two, as well as the missing of (LST) and (TST) of sequence three. It is started with the maximum flooding surface deposits, overlying the maximum flooding surface deposits of sequence two "KAl 7". The upper boundary is the highest point of the highstand systems tract deposits and equivalent to "KAl 8" (Bilal U. Haq, 2014), that represents the highest transgressive phase within the studied interval. It is approved by the first appearance of a number of palynomorphs. The palynomorphs species that are recorded are (Appendicisporites spp./Matonisporites phlebopteroides) in well-1, (Odontochitina spp) in well-2, (Coronifera spp./Cretacaeiporites scabratus/Elateroplicites africaensis/ Elaterosporites type-1 "Spiral”). This sequence could be distinguished into three parasequences, from base to top as:

Parasequence 3.1: It consists of a thick green glauconitic laminated claystone facies in well-1, and getting thin in the rest of the wells, that followed upward by cross-laminated and laminated sandstone facies of the overlying parasequence. The laminated claystone facies orientation is toward the NW trend, with average dip magnitude of $\left(4^{\circ}\right)$.

Parasequence 3.2: It represents the thickest sandstone facies interval that has a clear lateral continuity over the entire study area. It represents three stacked sandstone bodies that are composed mainly of crosslaminated, cross-bedded, laminated, and glauconitic bioturbated sandstone facies at some intervals. It is deposited mainly during the highstand systems tract stage (Figs. 11 \& 14), as it results in the deposition of stacked upper shoreface facies, whose thickness reaches $\sim 65 \mathrm{ft}$. over the entire study area. It represents an aggradational stacking pattern that downlap on the (MFS) subtidal mudstone facies.

The lower sandstone unit is built-up of a trough cross-bedded sandstone series with swinging dip azimuth trend from NNW to NNE with average dip magnitude of $\left(26^{\circ}\right)$ in well-2. The lower unit in the rest of study wells shows average dip magnitude of $\left(6^{\circ}\right)$ of laminated and cross-laminated facies, with unimodal dip azimuth trend toward the NNW. The clear unimodal NNW trend reflects that this unit is strongly affected by marine currents than the bi-directionality tidal current. It is also characterized by blocky wireline logs (GR -Neutron-Density) profile (Fig. 11).

The middle sandstone unit is characterized by multi-directions of the dip azimuth trends NW, ESE and WSW. It is composed mainly of cross-bedded, flaser bedded and convolute bedded sandstone facies. The multi-direction of azimuth trends reflect the combined effect of the longshore currents and tidal currents, with an equal energy level that avoids the appearance of one dominant trend within this unit (Fig. 11).

The upper sandstone unit is recorded only in well-1 and well-2. It is characterized by a NW dipping thick section of laminated sandstone facies. It shows unimodal dominated NW dip azimuth direction that reflects a strong current influence than tides. The average dip magnitude of this unit is 9o. The conventional open-hole logs demonstrate a blocky profile for this unit (Fig. 11).

Parasequence 3.3: It is composed of thinly laminated siltstone facies, which is considered as the top boundary of cycle three that forms its last foreshore deposits (Fig. 11). 


\section{Late Albian - Early Cenomanian Basin evolution}

The depositional sequence three is considered as the end of Albian age within the Bahariya Formation and the rest depositional sequences (4 and 5) are deposited during the Early Cenomanian age.

\section{Depositional Sequence (4): Intertidal to subtidal facies (KCe 1)}

Cycle four within the study area represents a regressive phase that results in the accumulation of tidally influenced sediments, that being composed of laminated siltstone, laminated sandstone, laminated claystone and sands, with a limited occurrence of intraclasts. Muddy heterolithics has been recorded in the study wells, except in well-3. Lenticular bedded sandstone facies has been observed in wells-1 and -2. Slumped mudstone facies has been recorded only in well-4 at the lower part of cycle four. There is a thick sandstone body recorded in well-3 and its thickness decrease in well-4, while changed to heterolithics and laminated siltstone facies in wells-1 and -2. In well-1, there are three tidal channels with NW to NNW trends interbedded with mixed flat deposits (Fig. 12). This sequence could be segmented into three parasequences, as follows from base to top:

Parasequence 4.1: It reflects the stage of global sea level fall that is supported by the presence of regressive facies that strongly influenced by tides and composed mainly of laminated sandstone, laminated siltstone, bioturbated sandstone, laminated claystone and massive siltstone facies intercalation. Flaser bedded sandstone facies has been observed only in wells- 1 and -3 . The dip data show WNW to NW dip azimuth trends, with a subordinate to the NE. Cross-laminated sandstone facies has been observed in well1, with SW dip azimuth trend. The facies reflects fining upward profile, followed by a coarsening upward trend in wells-1and -2, which indicate the deposition from high energy flow of tidal currents. The facies shows only a blocky to slightly coarsening upward profile in wells-3 and -4 , with intensive intercalations between the sandstone, siltstone and claystone facies that reflect the deposition in intertidal to shallow subtidal depositional suite (Fig. 12).

Parasequence 4.2: It is observed in three wells $-1,-3$ and -4 . It is built-up of laminated sandstone facies with the presence of cross-bedded sandstone only in well-3. This facies changes to intercalation of laminated siltstone, claystone and flaser bedded sandstone and bioturbated sandstone facies in well- 1 . The dip data shows unimodal northward dip azimuth trend in well-3, while well-2 displays a wide range of WNW-NW and NNW trends. Wells-3 and -4 reflect finning upward profile of stacked tidal channel deposits while well-1 represents mixed sand-mud flat deposits.

Parasequence 4. 3: It is composed mainly of laminated sandstone interbedded with cross-bedded sandstone facies, with a limited presence of pebbly sandstone in well-1. Lenticular bedded sandstone facies has been observed in wells-1 and -2, while migrating ripples have been observed in well-2. The deposits are dipping mainly towards the NNE trend, with subordinate NW in wells- 1 and -2 . The average dip magnitude is $3^{\circ}$ and $15^{\circ}$ for the laminated and cross-bedded sandstone facies, respectively, while the migrating ripples show increasing upward in the dip magnitude $\left(10^{\circ}\right.$ to $\left.20^{\circ}\right)$. It reflects blocky to slightly coarsening upward wireline gamma-ray log profile (Fig. 12).

\section{Depositional Sequence (5): Intertidal to shallow marine facies (KCe 2)}

The fifth depositional sequence within the study area consists mainly of glauconitic bioturbated, laminated, cross laminated and pebbly sandstone facies in addition to massive and laminated siltstone facies. Laminated, and massive claystone, as well as sandy and muddy heterolithics, have been observed also within the lower parasequence of sequence five. Bioturbated siltstone facies has been observed in two wells -1 and -3 at the top of heterolithics and laminated siltstone facies. The former reflects the flow energy fluctuations within the tidal inlet domain and results in the development of mixed flat areas. The claystone and siltstone facies within the uppermost parasequence is interpreted as basinal sediments. The main trends are NW, NNW, SE, E and NW, respectively, within wells-1, $-2,-3$ and -4 . The transgression increased with time to cover the entire area with carbonate facies of Abu Roash "G", which is considered the top datum horizon for the study area. It is subdivided into four parasequences:

Parasequence 5.1: It consists mainly of laminated siltstone, sandy heterolithics, muddy heterolithics and laminated claystone facies over the entire study area. Bioturbated siltstone facies has observed in well-3. 


\section{Hassan and Darwish}

The dip data displays dominant NNW to NW dip azimuth direction, overall the studied wells with subordinate toward the SW-SE in the well-1. There is a laminated sandstone facies has observed in well-4, with NW dip azimuth trend and is characterized by high resistivity response due to the presence of hydrocarbon. It is interpreted as stacked mixed sand-mud flat to sandy flat in this sub-cycle that is intersected by tidal channel deposits dipping toward the NW of well-4 (Fig. 13).

Parasequence 5.2: It is characterized by the clear finger print of marine sea level rise that resulted in the deposition of glauconitic laminated sandstone facies of lower shoreface depositional suite. There are a sandy facies characterized by unimodal dip azimuth trend toward the SE direction over the entire study area, related to a storm event "Tempestites" deposits. Laminated green mudstone facies has been detected in well-3 and well-4. Pebbly glauconitic sandstone and laminated sandstone facies have been found in well-3. There is a basinal mudstone streak separates the upper and lower sandstone intervals in well-3. The mudstone facies is interpreted as basinal mudstone facies that underlying a lower shoreface facies. The Lower shoreface sandstone facies has been charged with hydrocarbon from the nearby source rock (Fig. 13).

Parasequence 5.3: It has been observed in the entire study area except well-3. It is composed mainly of cross-laminated sandstone interbedded with laminated siltstone facies within all the wells except in well-2. It is overlying a mixed sandy heterolithics interval. The dip data shows a dominant NW dip azimuth trend. This sub-cycle is characterized by a coarsening upward profile in all wells (Fig. 13).

Parasequence 5.4: It is observed over the entire present work area. It is built-up of massive bioturbated mudstone interbedded with glauconitic pebbly and laminated sandstone facies in well-1 and well-2 while interbedded with laminated siltstone facies in both well-3 and well-4. The dip data show North to NNW trend in well-1 and well-2 while trend towards the SW in well-3 and well-4 (Fig.13).

The commonly accepted depositional model of such setting is that illustrated in (Fig. 15).

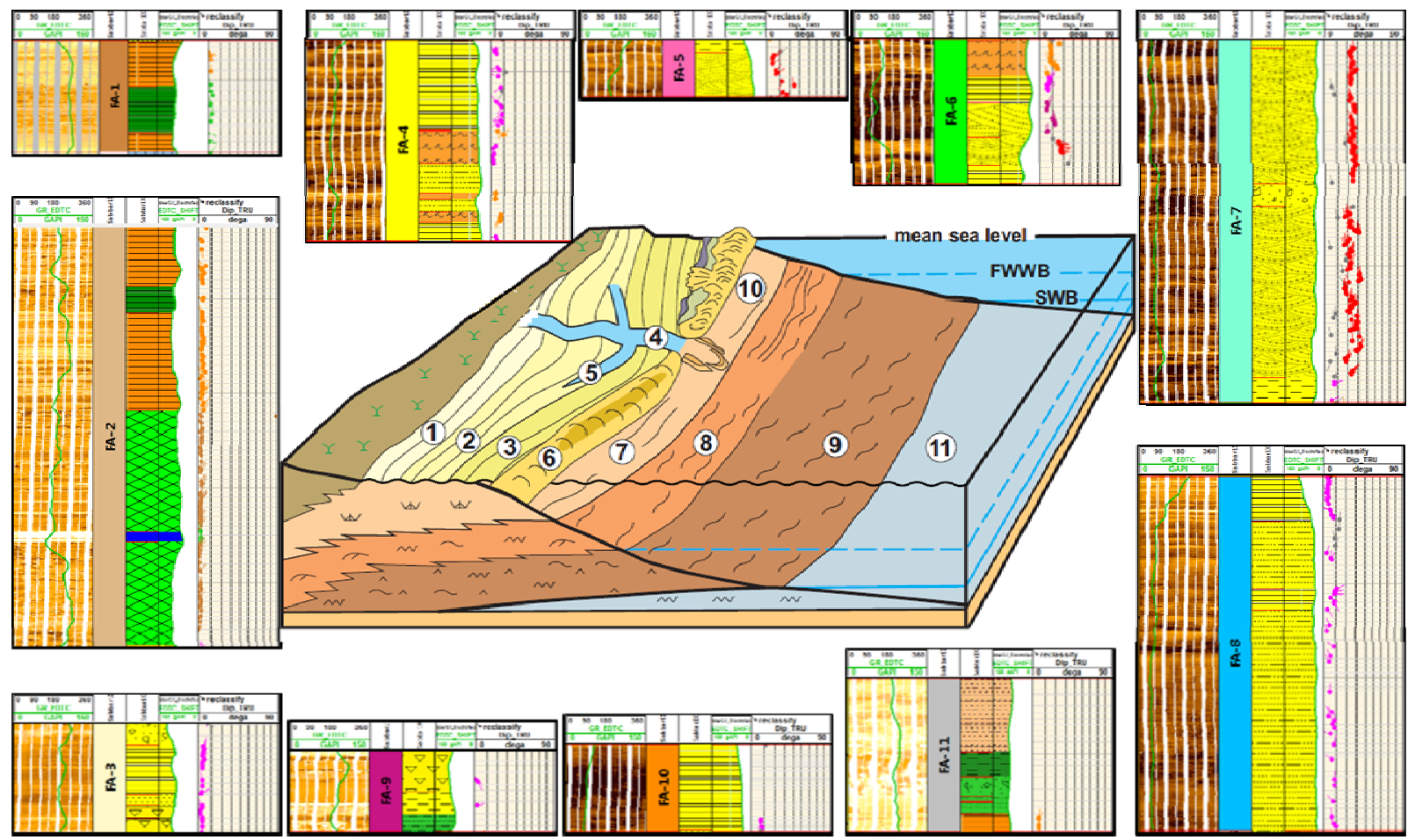

Fig. 15. Schematic depositional model for the study area with real examples of the interpreted depositional facies associations. 
Late Albian - Early Cenomanian Basin evolution

\section{CONCLUSIONS}

The Bahariya Formation in the East Ghazalat area has been distinguished into five depositional sequences ( 1 to 5 ) from bottom to top for the selected four wells. The sequences boundaries were identified lithologically by a basal mudstone facies (bases of cycles one, three, four and five) with a pronounced lime-muddy facies at the base of cycle two. It is approved by the palyno-chronostratigraphic analysis of the ditch cuttings of the study wells. High resolution palyno-biostratigraphic analysis used to support the main sequence boundaries. High Resolution FMI Analysis is calibrated to the core and used to build the depositional facies sequences. The recorded five sequences can be summarized as:

1. The lowermost sequence represents the mixed flat deposits that followed upwardly by sandstonedominated tidal channels accompanying the global sea level rise, and ended with a shallow marine carbonate bed.

2. The second sequence starts at the base with sand-dominated mixed flat deposits, denoting the early lowstand systems tracts of the next sea level rise, followed by shelfal mudstone facies. A nondepositional gap that supported by the presence of a hard ground terminated this sequence.

3. The third depositional sequence starts by the flooding event that represented by mudstone and shaly facies, followed upward by a continuous sea level rise building of vertically stacked shoreface facies forming an offshore sand bar.

4. The fourth sequence reflects relatively sea-level fall and is composed of a mixed flat that intersected by tidal channels and creek, and topped by shallow subtidal sediments.

5. The fifth sequence begins with a repeated sandy mixed flat that affected by storm event resulted in the deposition of tempestites and lower shoreface facies (trough and hummocky cross stratifications, in addition to glauconitic sandstone facies). It is ended up with the shallow subtidal carbonate facies of the base of Abu Roash Formation "G" member (upper Cenomanian).

6- The development of shoreface sandy facies of cycles three and five represents the maximum rate of sea level rise and developing the offshore sand bar system. These bars, due to sea level rise events, represent the high quality sandstone reservoirs, in addition to the tidal channels that may represent moderate to high quality reservoir.

\section{REFERENCES}

Darwish, M., (1994): Cenomanian-Turonian Sequence Stratigraphy, Basin Evolution and Hydrocarbon Potentialities of Northern Egypt, in Sadek, A., ed., The Geology of The Arab Word II : Cairo, Egypt, Cairo Univ., 261-303.

Darwish, M., and Tawfik, N., (2008): Sequence Stratigrapgy and Facies of the Jurassic- Lower Cretaceous Rift Systems in NE Africa, in Salem, M., El-Arnauti, A., and Saleh, A., eds., The Geology of East Libya, v.3: Tripoli, Libya, 3rd Symposium on the Sedimentary Basins of Libya, 345-368.

Dolson, J. C., Atta, M., Blanchard, D., Sehim, A., Villinski, J., Loutit, T., and Romine, K., (2014): Egypt's Future Petroleum Resources: A Revised Look into the 21st Century, in Marlow, L., Kendall, C., and Yose, L., eds., Petroleum systems of the Tethyan region: AAPG Memoir 106, 143-178.

Dominik, W., (1985): Stratigraphie Und Sedimentologie (Geochemie, Schwer-Mineralanayse) Der Oberkreide von Bahariya Und Ihre Korrelation Zum Dakhla Becken (Western Desert, Agypten), Berl. Geowiss. Abh. 50: 76-153.

El Toukhy,M., and Bakry, G., (1988): Bed-3, a Gas/condensate and Oil Field, Badr El Din Concession, Western Desert, Egypt, in Proceedings of the $9^{\text {th }}$ Petroleum Conf., 2: Cairo, Egypt, The Egyptian General Petroleum Corporation, 76-96.

Hameed El Redini, N.A., Bakr, A., Dahroug, S.M., In press., (2017): Seismic Data Interpretation for Hydrocarbon Potential , for Safwa/ Sabbar Field, East Ghazalat Onshore Area , Abu Gharadig Basin, Western Desert , Egypt, NRIAG Journal of Astronomy and Geophysics. 13. 


\section{Hassan and Darwish}

Hanter, G., (1990): North Western Desert, in R. Said, ed., The Geology of Egypt, 1: Rotterdam, Netherlands, A.A.Balkema Publishers, 293-319.

Haq, B. U., (2014): Cretaceous Eustasy Revisited, in Global and Planetary Change.113, Elsevier, 44-58.

Hataba, H.,and Ammar, G., (1990): Comparative Stratigraphic Study on the Upper Cenomanian-Lower Senonian Sediments between the Gulf of Suez and Western Desert, Egypt, in Proceedings of the 10th Petroleum Conference,.1: Cairo, Egypt, The Egyptian General Petroleum Corporation, 16.

Hermina, M., Klitzsch, E., and List, F. K., (1989): Stratigraphic Lexicon and Explanatory Notes to the Geological Map of Egypt 1: 500 000, in Conoco Inc.: Cairo, Egypt, 264.

Lagraba, P., Javier, O., Hansen, S. M., Spalburg, M., and Helmy, M., (2010): Borehole Image Tool Design, Value of Information, and Tool Selection, PÖppelreiter, M., Garcı́a-Carballido, C., and Kraaijveld, M., eds., Dipmeter and borehole image log technology: AAPG Memoir 92, 15-38.

Meshref, W. M., (1990): Tectonic Framework, in R. Said, ed., The Geology of Egypt, 1: Rotterdam, Netherlands, A. A.Balkema Publishers, 113-155.

Moustafa, A. R., (2008): Mesozoic-Cenozoic Basin Evolution in the Northern Western Desert of Egypt, in Salem, M., El-Arnauti, A., and Saleh, A., eds., The Geology of East Libya, v.3: Tripoli, Libya, 3rd Symposium on the Sedimentary Basins of Libya, 29-46.

Sultan, N., and Halim, M. A., (1988): Tectonic framework of Northern Western Desert, Egypt \& its effect on Hydrocarbon accumulations, in Proceedings of the 9th Petroleum Conference, 2: Cairo, Egypt, The Egyptian General Petroleum Corporation, 1-22.

Taher, M., Said, M., El Azhary, T., (1988): Organic geochemical study in Meleiha Area, Western Desert, Egypt, in Proceedings of the 9th Petroleum Conf., 2: Cairo, Egypt, The Egyptian General Petroleum Corporation, 190-212.

Wali, M., and Ayyad, A., (1988): Petrology and Source Potential of Abu Roash 'F' Limestone, Abu Sennan-Alam El Shawish Area, Western Desert, Egypt, in Proceedings of the $9^{\text {th }}$ Petroleum Conf., 2: Cairo, Egypt, The Egyptian General Petroleum Corporation, 164-189. 
Late Albian - Early Cenomanian Basin evolution

\section{تظور حوض ابو الغراديق في زمن الالبي المتاخر-السينوماني المبكر بتبع تحليل السحنات الرسوبية عالية الدقة -شمال الصحراء الغربية بمصر وطبيعتها الهيلروكريونية}

\section{سحر حسن و محمد درويش}

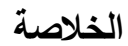

تثكل تتابعات العصر الطباشيري العلوي في شمال الصحراء الغربية -مصر - النظام البنرولي الرئيسي متمثلة في حوض الته

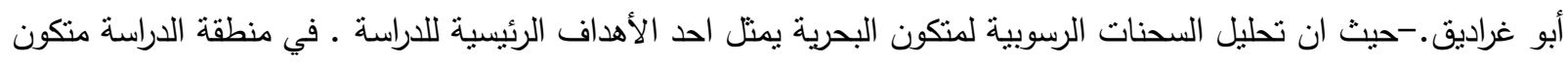
البحريه الرملي (ذو الطبيعة البحرية الضحلة) يعلو متكون الخريطة الرملي ذو السحنات الرملية النهرية على الأحجار الرملية

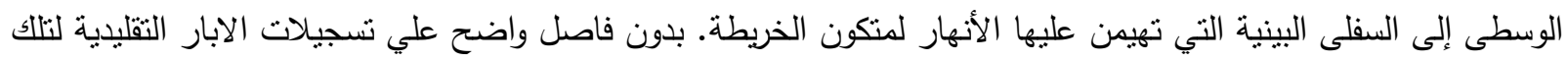

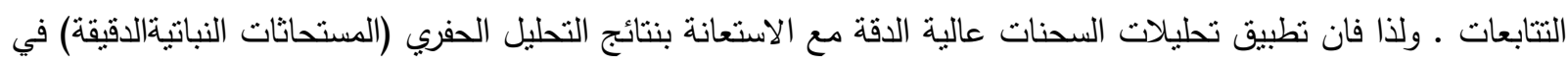
تفسير تسجيلات وصور الأبار (FMI)-ومقارنتها بالجسات المتاحه ساعد علي بناء النموذج الترسيبي للتتابعات الرملية في

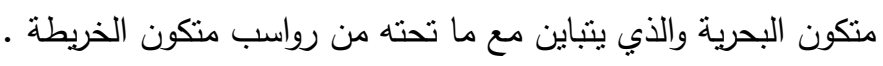

تم تميّيز متكون البحرية إلى خمسة تتابعات ترسيبية (من ا إلى 0) ، من الأسفل إلى الأعلى ، في الآبار موضوع الدراسة.

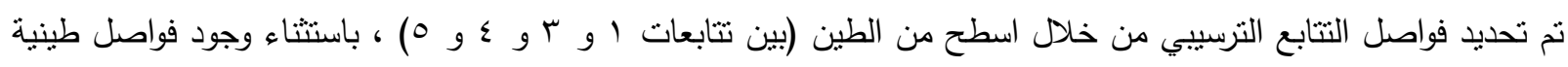

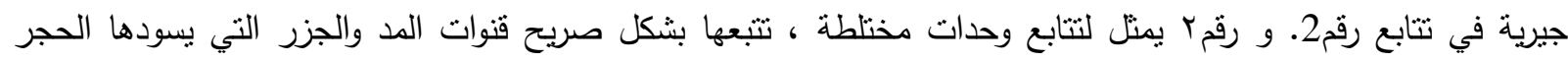

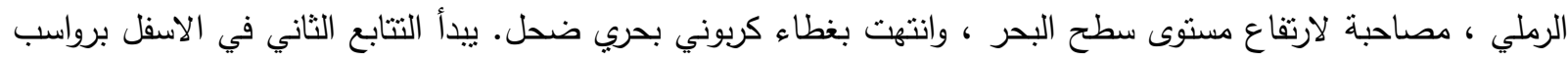

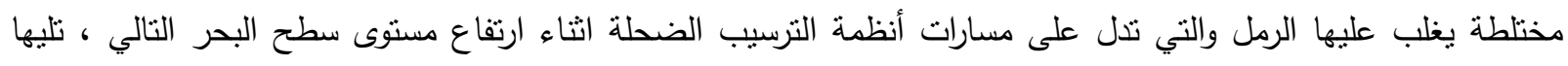

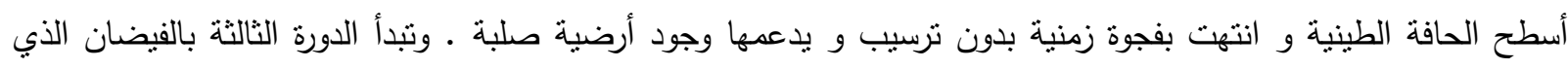

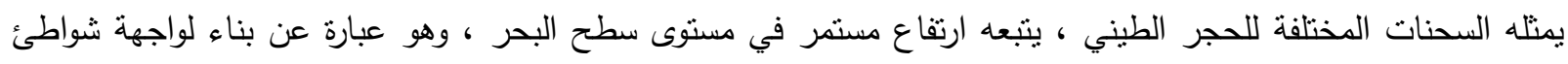

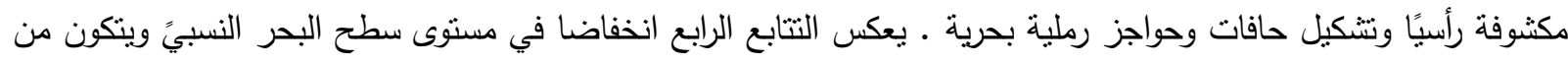

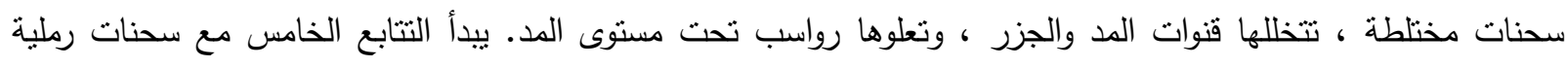

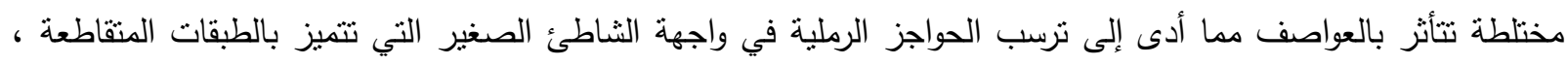
بالإضافة إلى طبقات الحجر الرملي الجلوكونيتي وانتهى بظهور كربونات بحرية ضحلة في مراحل المد والجزر لبداية متكون أبو رواش (السينوماني العلوي) •

ويمتل تطوير السحنات الرملية الساحلية للتتابعيين الثالث والخامس لأفصى معدل لارتفاع مستوى سطح البحر ، وتطور

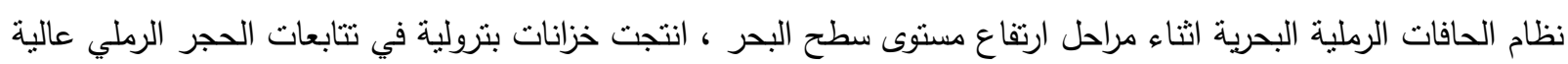
الجودة ، بالإضافة إلى قنوات المد والجزر ذات سيادة الحجر الرملي ، والتي قد تمنل خزانات بنرولية متوسطة-عالية الجودة . 